\title{
Increased body fat mass and androgen metabolism - A twin study in healthy young women
}

\author{
Veera Vihma $^{\mathrm{a}, \mathrm{b}, *}$, Sini Heinonen ${ }^{\mathrm{c}}$, Jussi Naukkarinen ${ }^{\mathrm{c}}$, Jaakko Kaprio ${ }^{\mathrm{d}}$, Aila Rissanen ${ }^{\mathrm{c}}$, \\ Ursula Turpeinen $^{\mathrm{e}}$, Esa Hämäläinen ${ }^{\mathrm{e}}$, Antti Hakkarainen ${ }^{\mathrm{f}}$, Jesper Lundbom ${ }^{\mathrm{f}}$, Nina Lundbom ${ }^{\mathrm{f}}$, \\ Tomi S. Mikkola ${ }^{\mathrm{b}, \mathrm{g}}$, Matti J. Tikkanen ${ }^{\mathrm{a}, \mathrm{b}}$, Kirsi H. Pietiläinen ${ }^{\mathrm{c}, \mathrm{h}}$ \\ ${ }^{\text {a }}$ University of Helsinki and Helsinki University Hospital, Heart and Lung Center, Biomedicum C315a, Haartmaninkatu 8, 00290 Helsinki, Finland \\ ${ }^{\mathrm{b}}$ Folkhälsan Research Center, P.O. Box 63, O0014 University of Helsinki, Finland \\ ${ }^{\mathrm{c}}$ University of Helsinki, Research Programs Unit, Diabetes and Obesity, Obesity Research Unit, P.O. Box 63, 00014 University of Helsinki, Finland \\ ${ }^{\mathrm{d}}$ University of Helsinki, FIMM, Institute for Molecular Medicine Finland, and Department of Public Health, P.O. Box 20, 00014 University of Helsinki, Finland \\ e Helsinki University Hospital, HUSLAB, P.O. Box 720, 00029 HUS, Helsinki, Finland \\ ${ }^{\mathrm{f}}$ University of Helsinki and HUS Medical Imaging Center, Helsinki University Hospital, Haartmaninkatu 4, 00290 Helsinki, Finland \\ ${ }^{\mathrm{g}}$ Helsinki University Hospital, Obstetrics and Gynecology, P.O. Box 140, 00029 HUS, Helsinki, Finland

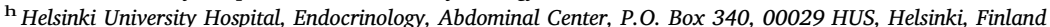

\section{A R T I C L E I N F O}

\section{Keywords:}

Adipose tissue

obesity

steroid hormone

dehydroepiandrosterone

steroid sulfatase

monozygotic twins

\begin{abstract}
A B S T R A C T
Objective: Obesity may alter serum steroid concentrations and metabolism. We investigated this in healthy young women with increased body fat and their leaner co-twin sisters.

Design: Age and genetic background both strongly influence serum steroid levels and body composition. This is a cross-sectional study of 13 female monozygotic twin pairs (age, 23-36 years), ten of which were discordant for body mass index (median difference in body weight between the co-twins, $19 \mathrm{~kg}$ ).

Methods: We determined body composition by dual energy X-ray absorptiometry and magnetic resonance imaging, serum androgens by liquid chromatography-tandem mass spectrometry, and mRNA expression of genes in subcutaneous adipose tissue and adipocytes.

Results: The heavier women had lower serum dehydroepiandrosterone (DHEA), dihydrotestosterone (DHT), and sex hormone-binding globulin (SHBG) $(P<0.05$ for all) compared to their leaner co-twins with no differences in serum testosterone or androstenedione levels. Serum DHEA correlated inversely with \%body fat $(r=-0.905$, $P=0.002)$, and DHT positively with SHBG $(r=0.842, P=0.002)$. In adipose tissue or adipocytes, expressions of STS (steroid sulfatase) and androgen-related genes were significantly higher in the heavier compared to the leaner co-twin, and within pairs, correlated positively with adiposity but were not related to serum androgen levels. None of the serum androgen or SHBG levels correlated with indices of insulin resistance.

Conclusions: Serum DHEA levels were best predicted by \%body fat, and serum DHT by SHBG. These or other serum androgen concentrations did not reflect differences in androgen-related genes in adipose tissue. General or intra-abdominal adiposity were not associated with increased androgenicity in young women.
\end{abstract}

\section{Introduction}

Adipose tissue is an important site of steroid hormone metabolism and action [1]. On one hand, steroid hormones may impact adipocyte proliferation and differentiation, lipid metabolism, and adipokine secretion, and these effects are gender and adipose tissue depot specific $[2,3]$. On the other hand, obesity and its related metabolic changes may exert effects on adipose tissue steroid metabolism. Interestingly, most of the steroid hormones acting at the adipose tissue level are synthesized locally from inactive steroid precursors [4]. Dehydroepiandrosterone

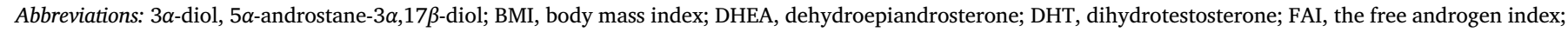

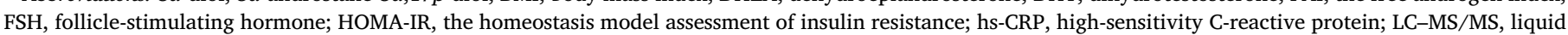

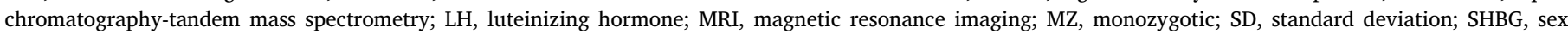
hormone-binding globulin

* Corresponding author at: Folkhälsan Research Center, Biomedicum C315a, Haartmaninkatu 8, P.O. Box 63, 00014 University of Helsinki, Finland.

E-mail address: veera.vihma@helsinki.fi (V. Vihma). 
(DHEA), DHEA sulfate, and androstenedione are secreted by the adrenals and ovaries and serve as circulating precursors for intra-tissue androgen and estrogen synthesis after diffusion, or for sulfated steroids, after active transport into the cells [5]. In addition to adrenal androgens, circulating estrone sulfate may serve as a precursor for the local synthesis of active estrogens in female adipose tissue [6].

Obesity is often associated with metabolic dysfunction of adipose tissue, including increased insulin resistance, lipolysis, and inflammation but the effects on sex steroid metabolic pathways are not well known. Obesity-related inflammation may lead to altered estrogen signaling via increased expression and activity of aromatase, as studied in breast adipose tissue [7]. Regarding androgen metabolism in adipose tissue, both activating and inactivating enzymes have been correlated with obesity [4], however, androgen inactivation may be the dominant pathway [8]. Androgens may impair differentiation of preadipocytes and adipogenesis in human female adipose tissue but the effects on lipid accumulation or lipolysis are not clear [2]. In addition to alterations in adipose tissue intracrinology, increased adiposity in women at different ages has been associated with higher circulating concentrations of total or bioavailable testosterone in cross-sectional $[9,10]$ or prospective studies [11], along with reduced serum sex hormone-binding globulin (SHBG) concentrations $[9,11]$. In fertile-aged women, the relation between body composition and serum androgen concentrations is not clear. Some studies have found a positive correlation between circulating free testosterone and waist to hip -ratio [12-14], and other studies a negative $[15,16]$ or no correlation [12] between serum total testosterone levels and central accumulation of fat.

Genetic factors and age appear to explain much of the variability in serum concentrations of steroid hormones $[17,18]$, and both of these are important determinants of body composition too, which may have confounded many previous studies. Therefore, to characterize associations between adiposity and sex steroid hormone metabolism in fertileaged women we studied young adult female monozygotic (MZ) twin pairs. The majority of them were discordant for body mass index (BMI; intra-pair difference in $\mathrm{BMI} \geq 3.0 \mathrm{~kg} / \mathrm{m}^{2}$, median, $6.6 \mathrm{~kg} / \mathrm{m}^{2}$ ) but naturally completely matched for genetic effects and age. Due to fluctuation of estrogen levels during the menstrual cycle, the emphasis in serum analyses was on androgen metabolites. In subcutaneous adipose tissue, we analyzed mRNA expressions of genes for steroid metabolizing enzymes of interest, and in a subgroup of twin pairs, gene expressions were also analyzed in isolated adipocytes.

\section{Experimental}

\subsection{Subjects and study design}

This is a cross-sectional study of rare BMI-discordant and randomly chosen BMI-concordant control MZ female twin pairs, aged 23-36 years, identified from ten full birth cohorts of Finnish twins [19]. The clinical characteristics of the women have been described in detail in [20-22]. For the present analyses, we identified 13 pairs, ten BMIdiscordant [within-pair difference $(\Delta)$ in $\mathrm{BMI} \geq 3 \mathrm{~kg} / \mathrm{m}^{2}$ ] and three concordant MZ twin pairs $\left(\Delta \mathrm{BMI}<3 \mathrm{~kg} / \mathrm{m}^{2}\right.$ ) who were either under no systemic hormonal therapy or used the same oral contraceptive regimen within the pair (see flow chart in Supplementary Fig. 1). For analyses of serum sex hormones and SHBG, we studied 10 twin pairs with no systemic hormonal therapy. Of them, seven women had an intrauterine progestin-releasing device (levonorgestrel $20 \mu \mathrm{g} / 24 \mathrm{~h}$; one full pair, and one leaner and one heavier co-twin from the BMI-discordant group, and one full pair and one leaner co-twin from the BMIconcordant group). In the larger group of 13 twin pairs, used for gene expression analyses, two BMI-discordant pairs used the same oral contraceptive containing $30 \mu \mathrm{g}$ ethinyl estradiol and $3 \mathrm{mg}$ drospirenon and one pair used $20 \mu \mathrm{g}$ ethinyl estradiol and $75 \mathrm{mg}$ gestoden. None of the women met the World Health Organization criteria for metabolic syndrome or had a diagnosis of polycystic ovary syndrome.
Both co-twins were examined at the same visit, with collection of blood samples, adipose tissue biopsies, and body composition measurements. Whole-body fat was measured by dual energy $\mathrm{x}$-ray absorptiometry, abdominal subcutaneous and intra-abdominal fat volume by magnetic resonance imaging (MRI), and liver fat by magnetic resonance spectroscopy as described previously [23]. The study was approved by the Ethics Committee of the Helsinki University Hospital and the twins gave written informed consent.

\subsection{Transcriptomics analyses of subcutaneous adipose tissue and isolated adipocytes}

Surgical biopsies of abdominal subcutaneous adipose tissue were taken from the periumbilical region under local anesthesia and snap frozen in liquid nitrogen. Adipocytes were isolated from part of the samples as previously described [24]. Total RNA for adipose tissue and adipocytes was extracted as described in [20]. Affymetrix U133 Plus 2.0 chips were used for transcriptomics analyses [21]. The Affymetrix data has been validated with RT-qPCR [21,22]. In the present study, we examined mRNA expression of genes for steroid metabolizing enzymes.

\subsection{Quantitative determination of serum hormones and other serum analyses}

Blood was drawn after an overnight fast between 0700 and $0900 \mathrm{~h}$, separated, and frozen at $-80{ }^{\circ} \mathrm{C}$ until assays. Serum DHEA [25], testosterone [26], and dihydrotestosterone (DHT) [27] concentrations were analyzed by liquid chromatography-tandem mass spectrometry (LC-MS/MS). To monitor the accuracy of serum testosterone and androstenedione quantitative assays across time, five common reference standard samples (UK National External Quality Assessment Service for Clinical Chemistry Birmingham) were analyzed monthly. For quantification of androstenedione, $20 \mu \mathrm{l}$ of $0.1 \mu \mathrm{M}{ }^{13} \mathrm{C}_{3}$-labelled androstenedione (IsoSciences, King of Prussia, USA) in $50 \%$ (v/v) methanol was added to $200 \mu \mathrm{l}$ of serum as internal standard (IS). The samples were extracted with $4 \mathrm{ml}$ of diethyl ether for $3 \mathrm{~min}$, and the upper layer was collected. After evaporation, the residue was dissolved in $1 \mathrm{ml}$ of $50 \%$ methanol. Calibrators containing $0.5-50 \mathrm{nmol} / 1$ of androstenedione (Vetranal, Sigma-Aldrich, St. Louis, USA) were prepared in $50 \%$ methanol. Samples and calibrators $(5 \mu \mathrm{l})$ were analysed with a LC-MS/MS system (TQ5500 triple quadrupole mass spectrometer, Sciex, Concord, Canada; and an Agilent series 1200 HPLC with a binary pump). The mobile phase on a SunFire C18 column $(2.1 \times 50 \mathrm{~mm}$; Waters, Milford, USA) was a linear gradient consisting of methanol and $100 \mu \mathrm{M}$ ammonium acetate in water (flow rate, $300 \mu \mathrm{l} / \mathrm{min}$ ). Androstenedione and IS were detected as a protonated ion in the positive mode with the following transitions: $\mathrm{m} / \mathrm{z} 287.1$ to $\mathrm{m} / \mathrm{z} 97.2$ and $109.2 ; \mathrm{m} / \mathrm{z} 290.1$ to $m / z 112.1$ (IS), respectively. Data were acquired with Analyst Software (version 1.6; Sciex). The linearity of standard curves was confirmed by plotting the peak area ratio of androstenedione to its IS (y) versus androstenedione concentration (x). The unknown sample concentrations were calculated from the weighted $\left(1 / \mathrm{x}^{2}\right)$ linear regression analysis of the standard curve. The method was linear at concentrations of $0.5-50 \mathrm{nmol} / 1$ (the assay quantitation range) with a correlation coefficient of $0.9995(n=10)$. The mean (SD) analytical recovery of serum spiked with androstenedione was $85(4.8) \%(n=17)$. The limit of detection was $30 \mathrm{pmol} / 1$ with a signal-to-noise ratio $>3$. The limit of quantification was determined as accuracy within $15 \%$ and precision $<20 \%$. Inter-assay coefficient variation $(<10 \%$ in ten assays) was calculated from repeated measurements of three quality-control samples (Lyphochek, Bio-Rad Laboratories, Inc., Hercules, USA). These serum-based control samples were analysed in every assay and stored at $-20^{\circ} \mathrm{C}$.

Serum SHBG, follicle-stimulating hormone (FSH) and luteinizing hormone (LH) were determined as described previously [28]. Serum free testosterone was calculated according to Anderson's equation 
$[28,29]$. Fasting plasma glucose, fasting serum insulin, serum highsensitivity C-reactive protein (hs-CRP) and serum adipokines were measured as described in [22]. Measures of insulin sensitivity/resistance (Matsuda index and the homeostasis model assessment of insulin resistance, HOMA-IR) were calculated from a $75 \mathrm{~g}$ oral glucose tolerance test [22].

\subsection{Statistical analysis}

Data are expressed as median (range) for variables with a nonnormal distribution, or as mean (standard deviation, SD). Differences between the leaner and heavier co-twins were assessed with Wilcoxon signed ranks test. Intra-pair difference ( $\Delta$ value) was calculated by subtracting the leaner twin's value from the heavier co-twin's value and used to evaluate associations between different clinical variables within pairs (Spearman's correlation or multivariate linear regression). Statistical analyses were performed using SPSS Statistics software (version 22.0). The level of significance (two-tailed) was $P<0.05$.

\section{Results}

\subsection{Clinical characteristics}

The clinical characteristics of 13 twin pairs including 10 pairs discordant for BMI are presented in Table 1. For BMI-discordant twin pairs, the median within-pair difference in body weight was $19 \mathrm{~kg}$ $(10-50 \mathrm{~kg})$, and the heavier co-twin had a median of $15 \mathrm{~kg}(9-30 \mathrm{~kg})$ more total body fat, $2.8(1.2-5.3)$ times more intra-abdominal fat and $3.9(1.1-10.3)$ times more liver fat compared to the leaner co-twin. The heavier co-twins also had higher circulating leptin levels and were more insulin resistant (Table 1).

\subsection{Serum androgen concentrations and adiposity in the heavier and leaner} co-twins

Concentrations of serum DHEA, DHT and SHBG were lower in the heavier compared to the leaner co-twins of the BMI-discordant pairs (Table 1). Serum androstenedione, total or free testosterone, the free androgen index (FAI, calculated as testosterone $\times 100 /$ SHBG), LH or FSH concentrations did not differ between the leaner and heavier cotwins (Table 1).

Next, we studied the associations between body fat distribution and serum androgen or SHBG concentrations within BMI-discordant and -concordant twin pairs and found the following inverse correlations: 1) $\Delta$ percent body fat with serum $\triangle$ DHEA (Fig. 1), 2) $\Delta$ intra-abdominal fat with $\triangle$ DHEA, $\triangle$ DHT, and $\triangle$ SHBG (Fig. 1), and $\triangle$ BMI and $\Delta$ subcutaneous fat with $\triangle$ SHBG $(\mathrm{r}=-0.804, P=0.005$, and $\mathrm{r}=-0.688, P=0.028$, respectively). Liver fat did not correlate with SHBG $(r=-0.115$, $P=0.75$ ) or with serum hormone concentrations (data not shown) within pairs. In agreement with SHBG being the principal carrier protein of serum DHT, $\triangle \mathrm{DHT}$ correlated strongly positively with $\triangle$ SHBG within pairs (Fig. 1). $\triangle$ DHEA did not correlate significantly with $\triangle$ SHBG ( $\mathrm{r}=0.619, P=0.10)$. Serum concentrations of androstenedione or total or free testosterone did not correlate with intra-abdominal adiposity ( $\Delta$ testosterone vs. $\Delta$ intra-abdominal fat, $\mathrm{r}=-0.333, P=0.35$; $\Delta$ free testosterone vs. $\Delta$ intra-abdominal fat, $\mathrm{r}=-0.006, P=0.99$ ) or with any other of the body composition measures within twin pairs (data not shown).

Table 1

Clinical characteristics of ten female monozygotic twin pairs discordant for BMI (within-pair difference in BMI $\geq 3 \mathrm{~kg} / \mathrm{m}^{2}$ ) and three female monozygotic twin pairs concordant for BMI (within-pair difference in BMI $<3 \mathrm{~kg} / \mathrm{m}^{2}$ ).

\begin{tabular}{|c|c|c|c|c|c|}
\hline Characteristic, median (range) & $\begin{array}{l}\text { BMI-discordant, Leaner } \\
(\mathrm{n}=10)\end{array}$ & $\begin{array}{l}\text { BMI-discordant, Heavier } \\
(\mathrm{n}=10)\end{array}$ & $\begin{array}{l}P \text { value for BMI-discordant, Heavier } \\
\text { vs. leaner }\end{array}$ & $\begin{array}{l}\text { BMI-concordant, } \\
\text { Leaner } \\
(\mathrm{n}=3)\end{array}$ & $\begin{array}{l}\text { BMI-concordant, Heavier } \\
(\mathrm{n}=3)\end{array}$ \\
\hline Age, years & $29(23-36)$ & $29(23-36)$ & & $32(31-34)$ & $32(31-34)$ \\
\hline Height, cm & $173(154-180)$ & $174(152-180)$ & 0.14 & $158(153-165)$ & $158(154-165)$ \\
\hline Weight, kg & $69(49-87)$ & $95(63-137)$ & 0.005 & $67(50-90)$ & $71(51-95)$ \\
\hline BMI, $\mathrm{kg} / \mathrm{m}^{2}$ & $23(20-31)$ & $31(25-43)$ & 0.005 & $27(21-33)$ & $29(21-35)$ \\
\hline Body fat, \% & $35(17-46)$ & $47(30-52)$ & 0.005 & $42(29-46)$ & $39(27-46)$ \\
\hline Subcutaneous fat, $\mathrm{cm}^{3}$ & $\begin{array}{l}3840 \\
(1360-6830)\end{array}$ & $\begin{array}{l}6280 \\
(4020-15100)\end{array}$ & 0.005 & $\begin{array}{l}5140 \\
(2150-6000)\end{array}$ & $\begin{array}{l}5060 \\
(2180-6490)\end{array}$ \\
\hline Intra-abdominal fat, $\mathrm{cm}^{3}$ & $\begin{array}{l}380 \\
(95-810)\end{array}$ & $\begin{array}{l}850 \\
(420-3150)\end{array}$ & 0.005 & $\begin{array}{l}590 \\
(570-1470)\end{array}$ & $\begin{array}{l}830 \\
(330-1420)\end{array}$ \\
\hline Ia to Sc fat -ratio, $\%$ & $9.8(3.9-20)$ & $11(8.7-41)$ & 0.013 & $25(11-27)$ & $16(15-22)$ \\
\hline Liver fat, $\%$ & $0.7(0.4-1.1)$ & $2.7(0.4-7.3)$ & 0.005 & $1.6(0.3-3.2)$ & $1.5(0.7-9.8)$ \\
\hline Smoker & $\mathrm{n}=3$ & $\mathrm{n}=1$ & & $\mathrm{n}=1$ & $\mathrm{n}=0$ \\
\hline Serum DHEA, nmol/l & $17(7.1-29)^{\mathrm{a}}$ & $9.7(7.0-21)^{\mathrm{a}}$ & 0.028 & $5.8(4.7-6.8)^{\mathrm{b}}$ & $6.2(4.7-7.7)^{\mathrm{b}}$ \\
\hline Serum androstenedione, $\mathrm{nmol} / \mathrm{l}$ & $3.9(2.5-6.9)$ & $3.1(2.6-4.9)$ & 0.50 & $2.7(2.2-4.6)$ & $3.2(2.9-4.3)$ \\
\hline Serum testosterone, nmol/1 & $0.78(0.6-2.9)$ & $0.74(0.6-1.4)$ & 0.45 & $0.79(0.4-1.1)$ & $0.94(0.9-1.1)$ \\
\hline Serum free testosterone, $\mathrm{pmol} / \mathrm{l}$ & $11(7.2-32)$ & $11(8.8-22)$ & 0.89 & $12(7.8-13)$ & $15(13-17)$ \\
\hline FAI & $2.0(1.0-4.0)$ & $2.5(1.5-4.1)$ & 0.24 & $2.1(1.7-2.3)$ & $3.5(1.8-4.6)$ \\
\hline Serum DHT, nmol/1 & $0.47(0.35-1.1)$ & $0.34(0.13-0.59)$ & 0.043 & $0.25(0.20-0.63)$ & $0.33(0.22-0.45)$ \\
\hline Serum SHBG, nmol/1 & $48(33-72)$ & $37(18-48)$ & 0.018 & $35(20-65)$ & $24(20-62)$ \\
\hline Serum LH, IU/1 & $5.6(1.6-7.0)$ & $6.9(1.9-10)$ & 0.77 & $3.9(3.1-6.4)$ & $6.1(4.8-8.0)$ \\
\hline Serum FSH, IU/1 & $5.2(1.7-7.1)$ & $4.1(2.2-6.1)$ & 0.26 & $5.3(3.6-7.5)$ & $5.8(5.7-6.4)$ \\
\hline Fasting serum insulin, mU/1 & $4.4(1.8-11)$ & $8.5(3.2-24)$ & 0.007 & $9.3(1.8-10)$ & $8.3(2.2-8.3)$ \\
\hline Fasting plasma glucose, mmol/1 & $5.0(4.6-5.7)$ & $5.4(4.7-6.0)$ & 0.11 & $5.0(4.7-5.6)$ & $4.9(4.8-5.5)$ \\
\hline HOMA-IR & $1.0(0.4-2.5)$ & $2.0(0.8-6.3)$ & 0.005 & $2.2(0.4-2.3)$ & $1.8(0.5-2.0)$ \\
\hline Matsuda index & $7.9(4.2-13.3)$ & $4.9(1.8-9.8)$ & 0.011 & $4.6(3.6-12.7)$ & $6.0(3.2-11.4)$ \\
\hline Hs-CRP, mg/l & $1.0(0.2-7.2)$ & $2.9(0.6-9.7)^{\mathrm{c}}$ & 0.07 & $1.5(0.1-2.0)$ & $0.5(0.1-2.5)$ \\
\hline Fasting plasma leptin, $\mu \mathrm{g} / \mathrm{l}$ & $25.6(2.4-57)$ & $59.2(8.7-71)$ & 0.005 & $27.4(6.3-53)$ & $21.8(7.7-65)$ \\
\hline Fasting plasma adiponectin, $\mu \mathrm{g} / 1$ & $\begin{array}{l}1950 \\
(4.5-4910)\end{array}$ & $\begin{array}{l}1780 \\
(2.6-3590)\end{array}$ & 0.07 & $\begin{array}{l}2190 \\
(4.1-2270)\end{array}$ & $\begin{array}{l}1700 \\
(4.9-2340)^{*}\end{array}$ \\
\hline
\end{tabular}

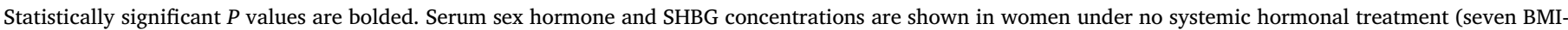

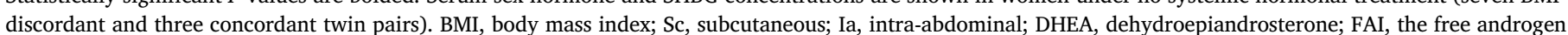

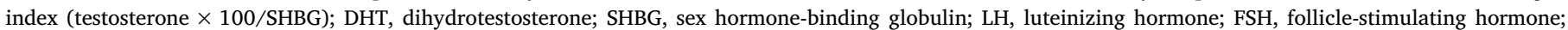

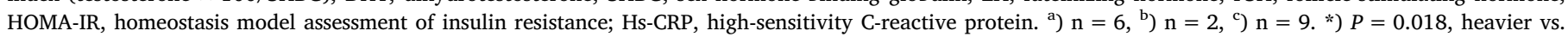
leaner, BMI-concordant twin pairs. 


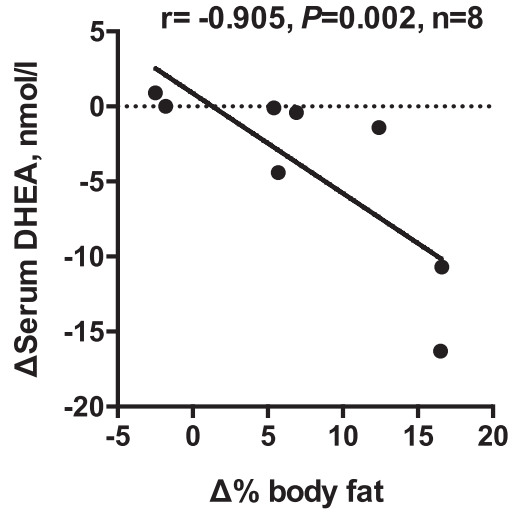

(a)

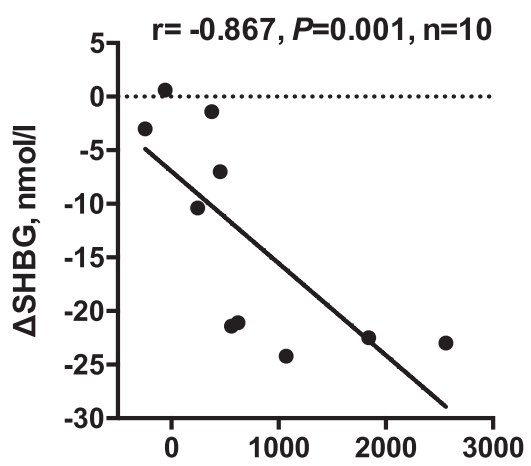

$\Delta$ Intra-abdominal fat, $\mathrm{cm}^{3}$

(c)

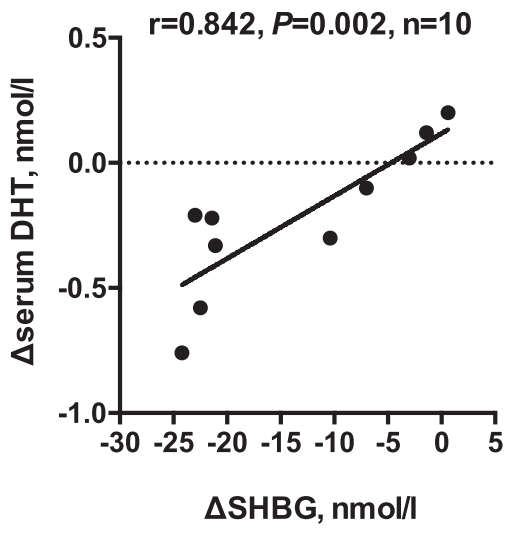

(e)

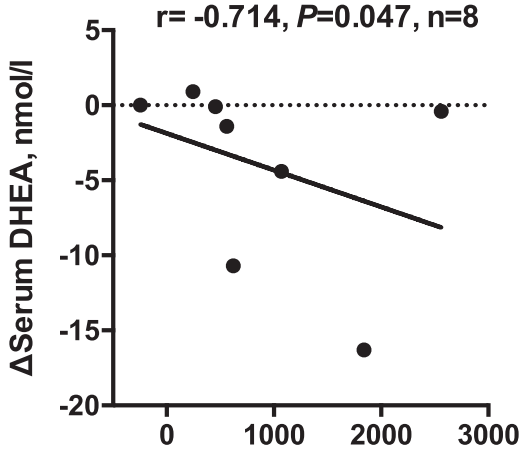

$\Delta$ Intra-abdominal fat, $\mathrm{cm}^{3}$

(b)

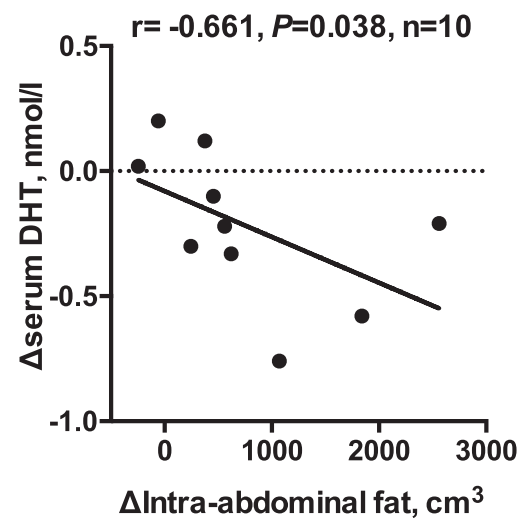

(d)
Fig. 1. Correlations between adiposity and serum DHEA, dihydrotestosterone or SHBG concentrations within twin pairs. (a) General adiposity correlated inversely with DHEA, intra-abdominal fat volume inversely with DHEA (b), SHBG (c) and dihydrotestosterone (d), and (e) SHBG positively with dihydrotestosterone concentration within 10 female monozygotic twin pairs [7 pairs discordant for body mass index ( $\triangle \mathrm{BMI} \geq 3 \mathrm{~kg} / \mathrm{m}^{2}$ ), and $3 \mathrm{BMI}$-concordant pairs. $\mathrm{N}=8$ pairs for $\Delta$ serum DHEA (6 BMI-discordant and 2 concordant twin pairs); Spearman's correlation]. Intra-pair difference ( $\Delta$ value) was calculated by subtracting the leaner twin's value from the heavier co-twin's value. Intra-abdominal fat volume was determined by magnetic resonance imaging, percent body fat by dual energy x-ray absorptiometry and serum hormone concentrations by LCMS/MS as described in the methods section. Least squares was the method used for curve fitting. DHEA, dehydroepiandrosterone; DHT, dihydrotestosterone; SHBG, sex hormone-binding globulin.
In multivariate analysis using linear regression, $\Delta$ percent body fat was an independent predictor of $\triangle$ DHEA in a model including $\Delta$ percent body fat, $\Delta$ subcutaneous fat, and $\Delta$ intra-abdominal fat as independent variables (Supplementary Table 1 ). $\triangle$ SHBG was the most significant predictor of $\Delta \mathrm{DHT}$ in a model including $\Delta$ percent body fat, $\Delta$ subcutaneous fat, $\Delta$ intra-abdominal fat, and $\triangle$ SHBG as independent variables (Supplementary Table 1). For serum SHBG, neither $\Delta$ percent body fat, $\Delta$ subcutaneous fat nor $\Delta$ intra-abdominal fat was an independent predictor (Supplementary Table 1).
3.3. Associations between serum androgen or SHBG levels and measures of insulin resistance within $M Z$ twin pairs

Within twin pairs, $\Delta$ testosterone correlated inversely with $\Delta$ fasting plasma insulin $(\mathrm{r}=-0.661, \quad P=0.038)$; the correlation of $\Delta$ testosterone with $\triangle$ HOMA-IR, a surrogate measure of hepatic insulin resistance, was weaker $(r=-0.624, P=0.054)$. When $\Delta$ adiposity was taken into account in a multivariate analysis, $\Delta$ fasting plasma insulin was no longer independently associated with $\Delta$ testosterone. No significant correlations of serum DHEA, androstenedione, free testosterone, DHT, SHBG, or FAI with fasting plasma insulin or glucose levels, or indices of insulin sensitivity/resistance within pairs were observed. 


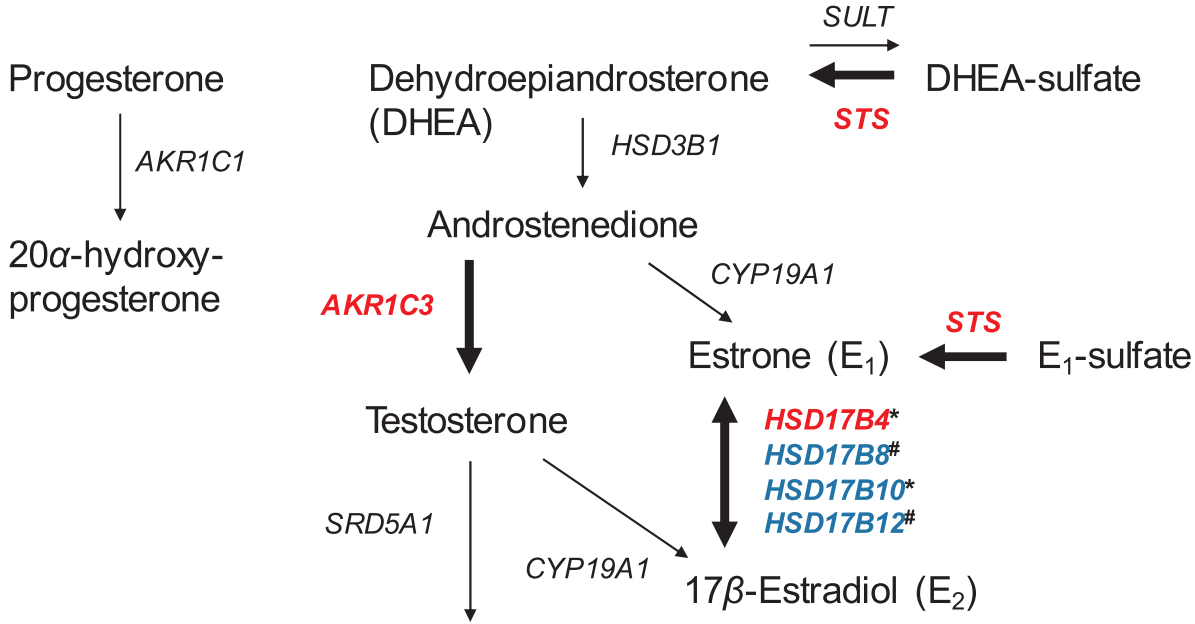

$5 \alpha$-Dihydrotestosterone (DHT)

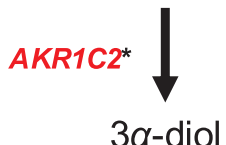

Fig. 2. A simplified scheme of steroid-metabolizing pathways of interest in female subcutaneous adipose tissue and in isolated adipocytes. The relative mRNA expressions of genes that differed between the heavier and leaner co-twin of the BMI-discordant pairs are indicated with bold arrows. Red denotes upregulation and blue downregulation of gene expression in the heavier vs. leaner monozygotic co-twins. Starting from the right-hand corner, the mRNA expression of STS (hydrolysis of DHEA sulfate and estrone sulfate) was upregulated in the heavier compared to the leaner co-twin. No significant expression of the sulfotransferases responsible for the reverse reaction (SULT1E1, SULT2A1, or SULT2B1) was detected. While the step from DHEA to androstenedione (HSD3B1) was not changed, the next step to testosterone (AKR1C3 expression) was significantly upregulated in the heavier co-twins. SRD5A1 (conversion of testosterone to DHT) expression did not differ between the co-twins, but AKR1C2 (inactivation of DHT to $3 \alpha$-diol) expression was upregulated in the heavier women's adipocytes. Several genes responsible for interconversion between estrone and 17 $\beta$-estradiol were also changed between the co-twins: HSD17B12 (reduction of estrone to $17 \beta$-estradiol, $P=0.047$ ) and $H S D 17 B 8$ (oxidation of $17 \beta$-estradiol to estrone,

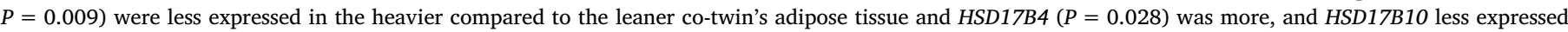

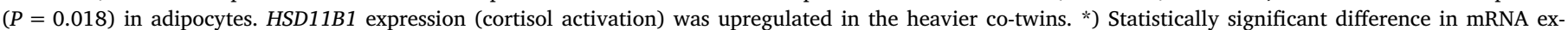

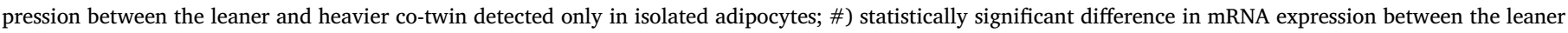

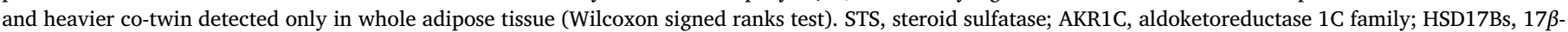
hydroxysteroid dehydrogenases; $3 \alpha$-diol, $5 \alpha$-androstane-3 $\alpha$,17 $\beta$-diol; HSD11B1, $11 \beta$-hydroxysteroid dehydrogenase 1 .

\section{4. mRNA expression of genes for steroid metabolizing enzymes in adipose} tissue or isolated adipocytes in the heavier and leaner co-twins

Those gene mRNA expressions that differed between the heavier and leaner co-twin of the BMI-discordant pairs are shown in Fig. 2, a simplified scheme of steroid hormone metabolic pathways. In both the whole adipose tissue and adipocytes, the mRNA expressions of STS (steroid sulfatase) and AKR1C3 (testosterone from androstenedione) were higher in the heavier compared to the leaner co-twin (Figs. 2 and 3). In addition, expression of AKR1C2 (inactivation of DHT) was upregulated in the heavier women's adipocytes (Figs. 2 and 3). In contrast, HSD17B12 (estrogen activation) and HSD17B8 (estrogen inactivation) were less expressed in the heavier compared to the leaner co-twin's adipose tissue (Fig. 2).

\subsection{Associations between mRNA expressions of genes and measures of adiposity within $M Z$ twin pairs}

Next, we assessed whether the magnitude or distribution of body fat associated with the genes that were differentially expressed between the heavier and leaner co-twins (Figs. 2 and 3). We found significant associations for six genes of the steroid metabolic pathway in at least one of the three body fat measures (Table 2). All associations were significant for percent body fat, five with subcutaneous fat and one with intra-abdominal fat (Table 2). Of the five adipose tissue gene expressions, percent body fat was the only explanatory factor accounting for the variation in gene expression in adipose tissue (Supplementary Table 2).

For isolated adipocytes, $\Delta$ subcutaneous fat correlated with $\Delta S T S$ $(\mathrm{r}=0.783, \quad P=0.013)$ and $\triangle A K R 1 C 2$ expressions $(\mathrm{r}=0.767$, $P=0.016$ ) and $\triangle$ intra-abdominal fat with $\triangle S T S$ and $\triangle A K R 1 C 2$ (Fig. 4). Interestingly, we additionally found out that $\triangle$ adipocyte $S T S$ expression was positively related to serum leptin concentration within twin pairs (Fig. 4). In multivariate analysis, intra-abdominal fat and/or leptin was important regarding adipocyte expressions of $\triangle S T S$ and $\triangle A K R 1 C 2$ (Supplementary Table 2). Serum adiponectin did not correlate with the adipocyte expression of $S T S$ within pairs $(r=0.233, P=0.55)$.

\section{Discussion}

We investigated androgen metabolism in relation to obesity in healthy young women aged 23-36 years. In the unique setting of MZ twin pairs discordant for BMI, the heavier women had much more total body fat compared to their leaner co-twins, providing the opportunity to analyze the associations between increased body fat, its distribution and hormonal parameters in women completely matched for genetic background, age and even many early environmental exposures. The heavier women had lower serum concentrations of the adrenal precursor androgen DHEA, DHT, the most potent androgen, and SHBG. Among adiposity variables, intra-abdominal fat was increased by almost threefold in the heavier co-twins and showed significant inverse correlations with serum DHEA, DHT and SHBG within pairs. Serum DHEA also correlated inversely with percent body fat, which was an independent predictor of its serum levels. In line with the present data, previous studies have reported inverse correlations between serum DHEA and BMI $[13,17,30]$. The results concerning correlations between serum DHEA and visceral fat content have been more variable $[9,10]$, and this can be explained, for example, by confounding by age, an important determinant of circulating DHEA in both sexes [31].

The sulfate ester of DHEA is the most abundant steroid in human blood and a source of active hormones produced locally in adipose tissue $[32,33]$. DHEA sulfate needs to be actively transported into the cell for hydrolysis by steroid sulfatase yielding free DHEA [5]. The gene expression of steroid sulfatase (STS) was significantly upregulated in the whole subcutaneous adipose tissue and in isolated adipocytes from the heavier compared to the leaner co-twins. We have recently shown in studies in vitro that hydrolysis of both DHEA sulfate [32] and estrone sulfate [6] take place in human subcutaneous and visceral adipose tissue suggesting that increased action of steroid sulfatase might, especially in postmenopausal women, provide more precursors for local estrogen synthesis, possibly even having some impact on serum levels. In young adult women with normal ovarian sex hormone production, a 


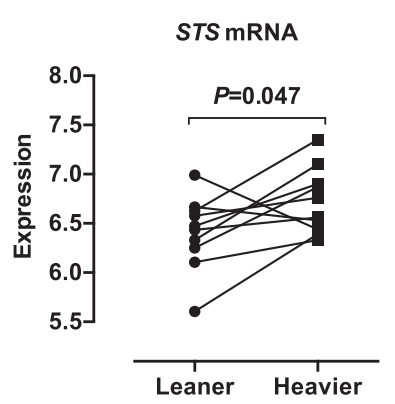

(a)

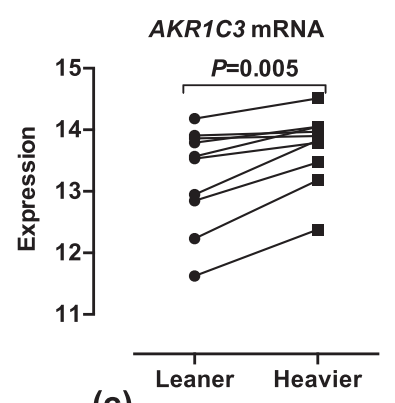

(c)

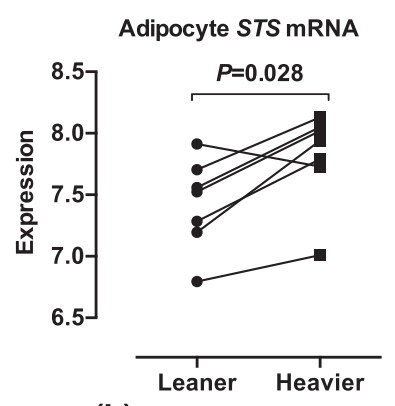

(b)
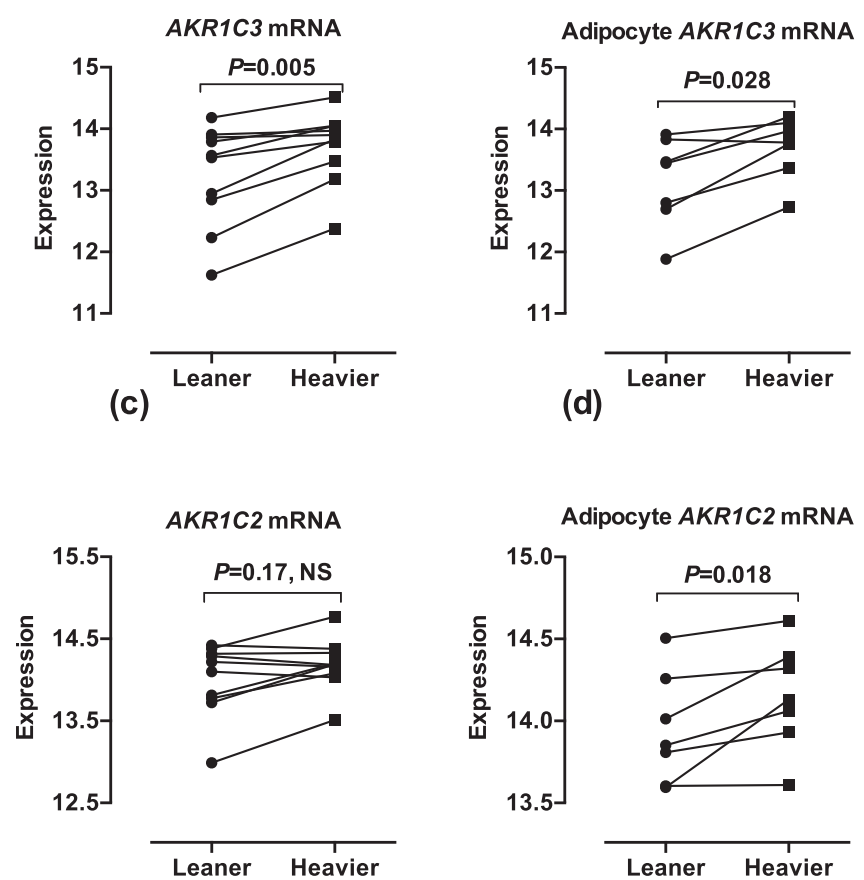

(e)

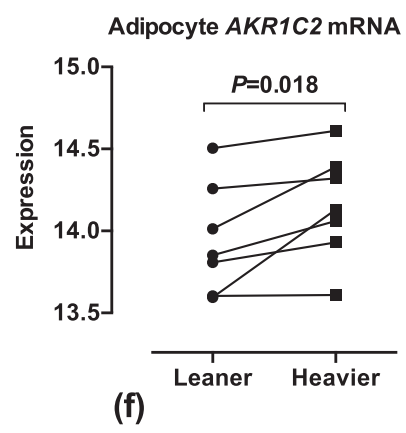

HSD11B1 mRNA

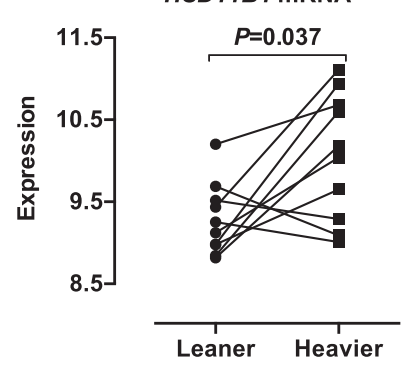

(g)

Fig. 3. mRNA expression of genes in the heavier and leaner co-twins in subcutaneous adipose tissue and in isolated adipocytes. The relative mRNA expression levels for genes of interest in abdominal subcutaneous adipose tissue (a), (c), (e), ( $\mathrm{g}$ ), and on the right, in isolated adipocytes in the heavier and leaner co-twins (b), (d), (f), (h) (Wilcoxon signed ranks test; $n=10$ female monozygotic twin pairs discordant for body mass index, $\Delta \mathrm{BMI} \geq 3 \mathrm{~kg} / \mathrm{m}^{2}$ ). $\mathrm{N}=7$ pairs for gene expressions in adipocytes.

possible increase in steroid sulfatase action would impact local steroid metabolism in fat tissue.

To the best of our knowledge, this is the first study describing a positive relation between adipocyte mRNA expression of STS and serum leptin. Leptin is an adipokine the synthesis of which is increased in obesity and which has been shown to stimulate aromatase expression in
Table 2

Correlations between within-pair differences $(\Delta)$ in adiposity and mRNA expression of genes in subcutaneous adipose tissue (13 female monozygotic twin pairs; Spearman's correlation).

\begin{tabular}{|c|c|c|c|c|}
\hline Subcutaneous adipose tissue & & $\Delta \%$ body fat & $\Delta \mathrm{Sc}$ fat, $\mathrm{cm}^{3}$ & $\Delta \mathrm{Ia}$ fat, $\mathrm{cm}^{3}$ \\
\hline \multirow[t]{2}{*}{$\Delta S T S$} & $\mathrm{r}$ & 0.819 & 0.648 & 0.335 \\
\hline & $P$ & 0.001 & 0.017 & 0.26 \\
\hline \multirow[t]{2}{*}{$\triangle A K R 1 C 1$} & $\mathrm{r}$ & 0.813 & 0.654 & 0.407 \\
\hline & $P$ & 0.001 & 0.015 & 0.17 \\
\hline \multirow[t]{2}{*}{$\triangle A K R 1 C 2$} & $\mathrm{r}$ & 0.797 & 0.533 & 0.198 \\
\hline & $P$ & 0.001 & 0.061 & 0.52 \\
\hline \multirow[t]{2}{*}{$\triangle A K R 1 C 3$} & $\mathrm{r}$ & 0.813 & 0.615 & 0.407 \\
\hline & $P$ & 0.001 & 0.025 & 0.17 \\
\hline \multirow[t]{2}{*}{$\triangle H S D 17 B 12$} & $\mathrm{r}$ & -0.824 & -0.780 & -0.549 \\
\hline & $P$ & 0.001 & 0.002 & 0.052 \\
\hline \multirow[t]{2}{*}{$\triangle H S D 11 B 1$} & $\mathrm{r}$ & 0.769 & 0.703 & 0.621 \\
\hline & $P$ & 0.002 & 0.007 & 0.024 \\
\hline
\end{tabular}

Statistically significant $P$ values are bolded. The within-pair differences ( $\Delta$ values) were calculated by subtracting the leaner twin's value from the heavier co-twin's value.

Sc, subcutaneous; Ia, intra-abdominal; r, correlation coefficient.

stromal adipose cells [34]. The present results suggest that leptin might be involved in the regulation of steroid sulfatase expression in adipocytes. However, as the actual steroid sulfatase enzyme activity does not necessarily correlate with its mRNA expression levels $[5,6]$, more studies are needed to clarify the role of leptin.

Serum concentrations of androstenedione, total or free testosterone, or FAI did not differ between the heavier and leaner female co-twins, nor did they correlate with intra-abdominal or general adiposity within pairs. Some studies have reported higher concentrations of bioavailable testosterone and thus, possibly greater androgenicity in women with increased visceral adiposity $[9,11]$, but our results indicate that this was not the case in healthy fertile-aged women. Consistent with our data, a randomized trial of weight loss among overweight premenopausal women did not find any significant associations between changes in the amount of visceral or subcutaneous adipose tissue with changes in serum testosterone [35]. In our study, the significant differences in mRNA expression of genes between the heavier and leaner co-twins suggested that the local metabolism of androgens and estrogens in fat tissue might be altered in obesity. The differences in adipose tissue gene expressions within twin pairs were not, however, associated with respective changes in hormone concentrations in the systemic circulation. In addition to STS, percent body fat correlated strongly positively with the expressions of AKR1C1, 2 and 3, and intra-abdominal fat volume was an independent predictor of higher STS and AKR1C2 expressions in isolated adipocytes, indicating that body fat distribution seemed to be related to upregulation of mRNA expression of these genes. One study has reported a positive correlation of BMI with the expression of AKR1C3 in subcutaneous fat, and even suggested a possible impact on circulating androgen levels [36]. Earlier studies using different methodology have yielded varying results on the correlation between central adiposity and serum androgen levels in premenopausal women [12,14-16] and studies directly comparing serum androgen levels between obese women and non-obese control women are rare [13]. Furthermore, many studies have included both premenopausal and peri- to postmenopausal women $[9,11,37]$, or only normal-weight women [10]. We believe that ours is the first study to compare serum androgen levels and adipose tissue gene expression of their metabolizing enzymes in fertile-aged women with increased body fat with their highly matched, substantially leaner controls.

Our data also demonstrate that in these healthy, young women, serum androgen or SHBG concentrations were not related to insulin sensitivity/resistance. Circulating SHBG has been previously shown to associate inversely with liver fat in men and women [38], however, in our study within female MZ twin pairs completely matched for age and 


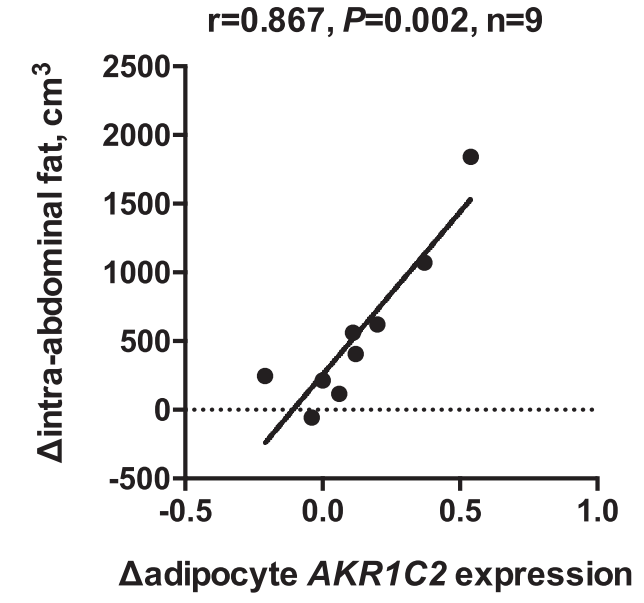

(a)

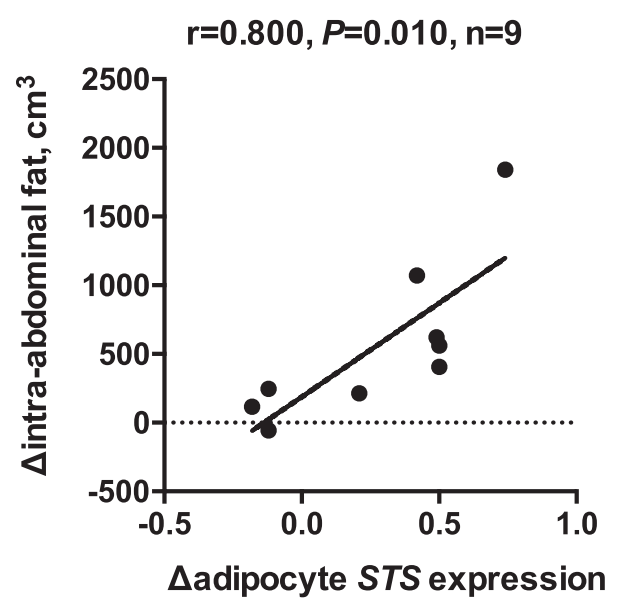

(b)

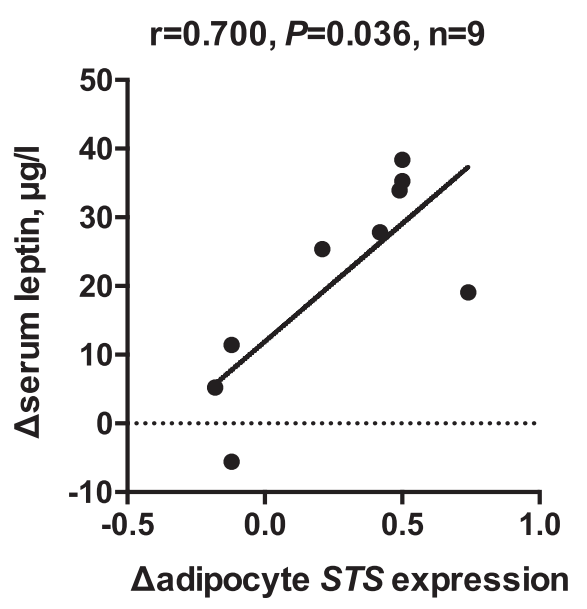

(c)

Fig. 4. Correlation between intra-abdominal adiposity or serum leptin with AKR1C2 or STS expressions in adipocytes within twin pairs. Intra-abdominal fat volume correlated positively with (a) mRNA expression of AKR1C2 and (b) STS, and (c) serum leptin concentration correlated positively with mRNA expression of STS in isolated adipocytes within nine female monozygotic twin pairs (Spearman's correlation). Intra-pair difference ( $\Delta$ value) was calculated by subtracting the leaner twin's value from the heavier co-twin's value. Intra-abdominal fat volume was determined by magnetic resonance imaging as described in the methods section. The method used for curve fitting was least genetic factors and fairly low liver fat values, no such correlation was observed. Serum SHBG was the best predictor of serum DHT concentration within pairs. Increased gene expression of DHT-inactivating AKR1C2 enzyme, while observed in isolated adipocytes, was not detected in whole subcutaneous adipose tissue from heavier women, leaving the possibility of enhanced catabolism of DHT unsupported. However, AKR1C2 expression in isolated adipocytes correlated strongly with intra-abdominal fat volume measured by MRI, in line with earlier studies reporting enhanced AKR1C mRNA expression and activity in omental adipose tissue in women with visceral obesity $[39,40]$.

Previously we have found decreased circulating SHBG and DHT concentrations as well as increased expression of AKR1C2 and AKR1C3 genes in subcutaneous adipose tissue from the heavier men in young adult male MZ twin pairs discordant for BMI [28]. Thus, in both sexes, increased adiposity seems to be associated with somewhat similar features in SHBG and androgen metabolism.

The strengths of our study include the carefully phenotyped MZ twin pairs discordant for BMI, a design where the lean and heavy study groups can be compared without confounding by genetic factors, age and sex. LC-MS/MS was used as the analytical method, and the accuracy of the steroid analytical method is especially important when analyzing relatively low androgen concentrations in women, or samples with a varying content of lipids. The limitations include the cross-sectional design which does not provide information about the direction of causation between adiposity and steroid metabolism. Also, ideally, protein levels and enzyme activities in the adipose tissue would complement gene expression results. All co-twins were examined at the same visit to minimize the diurnal or seasonal variation in circulating androgen or SHBG concentrations, but the twins could not be matched for the phase of the menstrual cycle. Due to the extreme rarity of BMIdiscordant MZ twin pairs, our sample size is small. This may reduce the statistical reliability of multivariate analysis.

In summary, we here show that independent of genetic effects and age, healthy, young adult women with increased body fat mass had lower serum concentrations of DHEA, DHT and SHBG compared to leaner women. Percent body fat was the best predictor of the serum level of DHEA, but for serum DHT level the concentration of its carrier protein, SHBG, was the best predictor. Previous reports linking female adiposity with androgenicity were not confirmed, and no independent associations between insulin sensitivity or resistance and serum levels of androgen or SHBG were observed. The increased expressions of steroid sulfatase and androgen-related genes in subcutaneous adipose tissue in heavier compared to leaner co-twins did not appear to influence serum steroid levels but may have influenced local steroid metabolism in adipose tissue.

\section{Acknowledgments}

This work was supported by Helsinki University Hospital; University of Helsinki; Folkhälsan Research Center; Academy of Finland (grant numbers 265240, 263278 for JK and 272376, 266286, 314383 for KHP); Sigrid Jusélius Foundation; Gyllenberg Foundation, Finnish Diabetes Research Foundation; Novo Nordisk Foundation; Finnish Foundation for Cardiovascular Research; and Päivikki and Sakari Sohlberg Foundation. We thank Mikko Haanpää (HUSLAB, Helsinki University Hospital), and Katja Sohlo and Mia Urjansson (Obesity Research Unit, University of Helsinki) for expert technical assistance, the team at the Obesity Research Unit, and the twins for their invaluable contribution.

\section{Declarations of interest}

None. 


\section{Appendix A. Supplementary data}

Supplementary data associated with this article can be found, in the online version, at https://doi.org/10.1016/j.steroids.2018.08.006.

\section{References}

[1] A. Tchernof, M.F. Mansour, M. Pelletier, M.M. Boulet, M. Nadeau, V. Luu-The, Updated survey of the steroid-converting enzymes in human adipose tissues, J. Steroid Biochem. Mol. Biol. 147 (2015) 56-69.

[2] M.W. O'Reilly, P.J. House, J.W. Tomlinson, Understanding androgen action in adipose tissue, J. Steroid Biochem. Mol. Biol. 143 (2014) 277-284.

[3] A.E. Newell-Fugate, The role of sex steroids in white adipose tissue adipocyte function, Reproduction 153 (2017) R133-R149.

[4] L. Schiffer, W. Arlt, K.H. Storbeck, Intracrine androgen biosynthesis, metabolism and action revisited, Mol. Cell. Endocrinol. 465 (2018) 4-26.

[5] J.W. Mueller, L.C. Gilligan, J. Idkowiak, W. Arlt, P.A. Foster, The regulation of steroid action by sulfation and desulfation, Endocr. Rev. 36 (2015) 526-563.

[6] N. Hetemäki, H. Savolainen-Peltonen, M.J. Tikkanen, F. Wang, H. Paatela, E. Hämäläinen, U. Turpeinen, M. Haanpää, V. Vihma, T.S. Mikkola, Estrogen metabolism in abdominal subcutaneous and visceral adipose tissue in postmenopausal women, J. Clin. Endocrinol. Metab. 102 (2017) 4588-4595.

[7] C. Gérard, K.A. Brown, Obesity and breast cancer - Role of estrogens and the molecular underpinnings of aromatase regulation in breast adipose tissue, Mol. Cell. Endocrinol. 466 (2018) 15-30.

[8] K. Blouin, A. Veilleux, V. Luu-The, A. Tchernof, Androgen metabolism in adipose tissue: recent advances, Mol. Cell. Endocrinol. 301 (2009) 97-103.

[9] M.L. Mongraw-Chaffin, C.A. Anderson, M.A. Allison, P. Ouyang, M. Szklo, D. Vaidya, M. Woodward, S.H. Golden, Association between sex hormones and adiposity: qualitative differences in women and men in the Multi-Ethnic Study of Atherosclerosis, J. Clin. Endocrinol. Metab. 100 (2015) E596-E600.

[10] J.L. Keller, P.R. Casson, M.J. Toth, Relationship of androgens to body composition, energy and substrate metabolism and aerobic capacity in healthy, young women, Steroids 76 (2011) 1247-1251.

[11] R.P. Wildman, P.G. Tepper, S. Crawford, J.S. Finkelstein, K. Sutton-Tyrrell, R.C. Thurston, N. Santoro, B. Sternfeld, G.A. Greendale, Do changes in sex steroid hormones precede or follow increases in body weight during the menopause transition? Results from the Study of Women's Health Across the Nation, J. Clin. Endocrinol. Metab. 97 (2012) E1695-E1704.

[12] D.J. Evans, R.G. Hoffmann, R.K. Kalkhoff, A.H. Kissebah, Relationship of androgenic activity to body fat topography, fat cell morphology, and metabolic aberrations in premenopausal women, J. Clin. Endocrinol. Metab. 57 (1983) 304-310.

[13] G. De Pergola, V.A. Giagulli, G. Garruti, M.R. Cospite, F. Giorgino, M. Cignarelli, R. Giorgino, Low dehydroepiandrosterone circulating levels in premenopausal obese women with very high body mass index, Metabolism 40 (1991) 187-190.

[14] S.B. Pedersen, J.D. Borglum, K. Brixen, B. Richelsen, Relationship between sex hormones, body composition and metabolic risk parameters in premenopausal women, Eur. J. Endocrinol. 133 (1995) 200-206.

[15] F. Armellini, M. Zamboni, S. Castelli, R. Robbi, A. Mino, T. Todesco, I.A. BergamoAndreis, O. Bosello, Interrelationships between intraabdominal fat and total serum testosterone levels in obese women, Metabolism 43 (1994) 390-395.

[16] G. De Pergola, V. Triggiani, F. Giorgino, M.R. Cospite, G. Garruti, M. Cignarelli, E. Guastamacchia, R. Giorgino, The free testosterone to dehydroepiandrosterone sulphate molar ratio as a marker of visceral fat accumulation in premenopausal obese women, Int. J. Obes. Relat. Metab. Disord. 18 (1994) 659-664.

[17] O. Ukkola, J. Gagnon, T. Rankinen, P.A. Thompson, Y. Hong, A.S. Leon, D.C. Rao, J.S. Skinner, J.H. Wilmore, C. Bouchard, Age, body mass index, race and other determinants of steroid hormone variability: the HERITAGE Family Study, Eur. J Endocrinol. 145 (2001) 1-9.

[18] E. Turcato, M. Zamboni, G. De Pergola, F. Armellini, A. Zivelonghi, I.A. BergamoAndreis, R. Giorgino, O. Bosello, Interrelationships between weight loss, body fat distribution and sex hormones in pre- and postmenopausal obese women, J. Intern. Med. 241 (1997) 363-372.

[19] J. Kaprio, Twin studies in Finland, Twin Res Hum. Genet. 9 (2006) 772-777.

[20] S. Heinonen, J. Buzkova, M. Muniandy, R. Kaksonen, M. Ollikainen, K. Ismail, A. Hakkarainen, J. Lundbom, N. Lundbom, K. Vuolteenaho, E. Moilanen, J. Kaprio, A. Rissanen, A. Suomalainen, K.H. Pietiläinen, Impaired mitochondrial biogenesis in adipose tissue in acquired obesity, Diabetes 64 (2015) 3135-3145.

[21] S. Jukarainen, S. Heinonen, J.T. Rämö, R. Rinnankoski-Tuikka, E. Rappou, M. Tummers, M. Muniandy, A. Hakkarainen, J. Lundbom, N. Lundbom, J. Kaprio, A. Rissanen, E. Pirinen, K.H. Pietiläinen, Obesity is associated with low NAD/SIRT pathway expression in adipose tissue of BMI-discordant monozygotic twins, J. Clin.
Endocrinol. Metab. 101 (2015) 275-283.

[22] J. Naukkarinen, S. Heinonen, A. Hakkarainen, J. Lundbom, K. Vuolteenaho, L. Saarinen, S. Hautaniemi, A. Rodriguez, G. Frühbeck, P. Pajunen, T. Hyötyläinen, M. Orešič, E. Moilanen, A. Suomalainen, N. Lundbom, J. Kaprio, A. Rissanen, K.H. Pietiläinen, Characterising metabolically healthy obesity in weight-discordant monozygotic twins, Diabetologia 57 (2014) 167-176.

[23] J. Lundbom, A. Bierwagen, K. Bodis, J. Szendrödi, J. Kaprio, A. Rissanen, N. Lundbom, M. Roden, K.H. Pietiläinen, Deep subcutaneous adipose tissue lipid unsaturation associates with intramyocellular lipid content, Metabolism 65 (2016) 1230-1237.

[24] S. Heinonen, M. Muniandy, J. Buzkova, A. Mardinoglu, A. Rodríguez, G. Frühbeck, A. Hakkarainen, J. Lundbom, N. Lundbom, J. Kaprio, A. Rissanen, K.H. Pietiläinen, Mitochondria-related transcriptional signature is downregulated in adipocytes in obesity: a study of young healthy MZ twins, Diabetologia 60 (2017) 169-181.

[25] F. Wang, A. Koskela, E. Hämäläinen, U. Turpeinen, H. Savolainen-Peltonen, T.S. Mikkola, V. Vihma, H. Adlercreutz, M.J. Tikkanen, Quantitative determination of dehydroepiandrosterone fatty acyl esters in human female adipose tissue and serum using mass spectrometric methods, J. Steroid Biochem. Mol. Biol. 124 (2011) 93-98.

[26] U. Turpeinen, S. Linko, O. Itkonen, E. Hämäläinen, Determination of testosterone in serum by liquid chromatography-tandem mass spectrometry, Scand. J. Clin. Lab. Invest. 68 (2008) 50-57.

[27] E. Pöllänen, S. Sipilä, M. Alen, P.H. Ronkainen, C. Ankarberg-Lindgren, J. Puolakka, H. Suominen, E. Hämäläinen, U. Turpeinen, Y.T. Konttinen, V. Kovanen, Differential influence of peripheral and systemic sex steroids on skeletal muscle quality in pre- and postmenopausal women, Aging Cell 10 (2011) 650-660.

[28] V. Vihma, J. Naukkarinen, U. Turpeinen, E. Hämäläinen, J. Kaprio, A. Rissanen, S. Heinonen, A. Hakkarainen, J. Lundbom, N. Lundbom, T.S. Mikkola, M.J. Tikkanen, K.H. Pietiläinen, Metabolism of sex steroids is influenced by acquired adiposity - a study of young adult male monozygotic twin pairs, J. Steroid Biochem. Mol. Biol. 172 (2017) 98-105.

[29] D.C. Anderson, M.O. Thorner, R.A. Fisher, J.P. Woodham, H.L. Goble, G.M. Besser, Effects of hormonal treatment on plasma unbound androgen levels in hirsute women, Acta Endocrinol. Suppl. (Copenh.) 199 (1975) 224.

[30] G. De Pergola, M. Zamboni, M. Sciaraffia, E. Turcato, N. Pannacciulli, F. Armellini, F. Giorgino, S. Perrini, O. Bosello, R. Giorgino, Body fat accumulation is possibly responsible for lower dehydroepiandrosterone circulating levels in premenopausal obese women, Int. J. Obes. Relat. Metab. Disord. 20 (1996) 1105-1110.

[31] F. Labrie, A. Bélanger, L. Cusan, J.L. Gomez, B. Candas, Marked decline in serum concentrations of adrenal C19 sex steroid precursors and conjugated androgen metabolites during aging, J. Clin. Endocrinol. Metab. 82 (1997) 2396-2402.

[32] H. Paatela, F. Wang, V. Vihma, H. Savolainen-Peltonen, T.S. Mikkola, U. Turpeinen, E. Hämäläinen, M. Jauhiainen, M.J. Tikkanen, Steroid sulfatase activity in subcutaneous and visceral adipose tissue: a comparison between pre- and postmenopausal women, Eur. J. Endocrinol. 174 (2016) 167-175.

[33] F. Labrie, C. Martel, A. Bélanger, G. Pelletier, Androgens in women are essentially made from DHEA in each peripheral tissue according to intracrinology, J. Steroid Biochem. Mol. Biol. 168 (2017) 9-18.

[34] H. Zahid, K. Subbaramaiah, N.M. Iyengar, X.K. Zhou, I.C. Chen, P. Bhardwaj, A. Gucalp, M. Morrow, C.A. Hudis, A.J. Dannenberg, K.A. Brown, Leptin regulation of the p53-HIF1alpha/PKM2-aromatase axis in breast adipose stromal cells - a novel mechanism for the obesity-breast cancer link, Int. J. Obes. (Lond.) 42 (2018) 711-720.

[35] C. Kim, D. Dabelea, R.R. Kalyani, C.A. Christophi, G.A. Bray, X. Pi-Sunyer, C.H. Darwin, S. Yalamanchi, E. Barrett-Connor, S.H. Golden, E.J. Boyko, Changes in visceral adiposity, subcutaneous adiposity, and sex hormones in the Diabetes Prevention Program, J. Clin. Endocrinol. Metab. 102 (2017) 3381-3389.

[36] M. Quinkler, B. Sinha, J.W. Tomlinson, I.J. Bujalska, P.M. Stewart, W. Arlt, Androgen generation in adipose tissue in women with simple obesity - a site-specific role for 17beta-hydroxysteroid dehydrogenase type 5, J. Endocrinol. 183 (2004) 331-342.

[37] J.A. Côté, J. Lessard, J. Mailloux, P. Laberge, C. Rhéaume, A. Tchernof, Circulating 5alpha-dihydrotestosterone, abdominal obesity and adipocyte characteristics in women, Horm. Mol. Biol. Clin. Investig. 12 (2012) 391-400.

[38] A. Peter, K. Kantartzis, J. Machann, F. Schick, H. Staiger, F. Machicao, E. Schleicher, A. Fritsche, H.U. Häring, N. Stefan, Relationships of circulating sex hormonebinding globulin with metabolic traits in humans, Diabetes 59 (2010) 3167-3173.

[39] K. Blouin, C. Richard, C. Bélanger, P. Dupont, M. Daris, P. Laberge, V. Luu-The, A. Tchernof, Local androgen inactivation in abdominal visceral adipose tissue, J. Clin. Endocrinol. Metab. 88 (2003) 5944-5950.

[40] K. Blouin, S. Blanchette, C. Richard, P. Dupont, V. Luu-The, A. Tchernof, Expression and activity of steroid aldoketoreductases $1 \mathrm{C}$ in omental adipose tissue are positive correlates of adiposity in women, Am. J. Physiol. Endocrinol. Metab. 288 (2005) E398-E404. 